\title{
Comparative Antimicrobial Effectiveness of Two Medicated Soaps with Herbal Soap from Morinda morindoides (Rubiaceae) against Skin Pathogens
}

\author{
TOURE Abdoulaye ${ }^{1,2, *}$, MEITE Souleymane ${ }^{2,3}$, OUATTARA Howele ${ }^{1}$, SORO Yade Rene, \\ DJAMAN Allico Joseph ${ }^{2,3}$, COULIBALY Adama ${ }^{2}$ \\ ${ }^{1}$ Biological Sciences Faculty, University Peleforo Gon Coulibaly, Korhogo, Cote d’Ivoire \\ ${ }^{2}$ Biochemical Pharmacodynamy Laboratory, Biosciences Faculty, University Felix Houphouet Boigny, Abidjan, Cote d’Ivoire \\ ${ }^{3}$ Clinical Biochemistry Laboratory, Institut Pasteur of Cote d'Ivoire, Abidjan, Cote d'Ivoire \\ ${ }^{4}$ Biotechnology Laboratory, Biosciences Faculty, University Felix Houphouet Boigny, Abidjan, Cote d’Ivoire \\ *Corresponding author: tourabdoulaye@yahoo.fr
}

\begin{abstract}
In present study two medicated soaps namely Pharmaderm and Micoderme and herbal soap Morinda formulated with fat extracted from leaves of Morinda morindoides (Rubiaceae) were investigated for their antimicrobial activities against some clinical strains for skin.diseases. The purpose of this study was to verify and compare their antimicrobial effectiveness. Agar broth dilution method with Sabouraud and Mueller-Hinton at serial concentrations of soaps ranging from 62.50 to $3.9 \mathrm{mg} / \mathrm{ml}$ and agar plate method were used to determine antimicrobial parameters. All strains tested were inhibited significantly $(\mathrm{p}<0.05)$ by different types of soaps with minimal fungicidal concentration (MFC) ranging from $62.50-7.81 \mathrm{mg} / \mathrm{ml}$ and minimal bactericidal concentration (MBC) between $31.25-7.81 \mathrm{mg} / \mathrm{ml}$. Soap Micoderme exhibited highest antimicrobial effectiveness with MFC varying from 7.81 to $31.25 \mathrm{mg} / \mathrm{ml}$ and MBC of $15.62 \mathrm{mg} / \mathrm{ml}$. Soaps Morinda and Pharmaderm showed similar antibacterial activities with MBC of $31.25 \mathrm{mg} / \mathrm{ml}$. Soap Morinda with MFC of $31.25 \mathrm{mg} / \mathrm{ml}$ was more effectiveness than soap Pharmaderm (MFC of $62.50 \mathrm{mg} / \mathrm{ml}$ ) against all fungi. T. mentagrophytes was most sensitive fungi whereas $C$. albicans was least strain in presence of tested soaps. S. aureus was the most resistant among testing bacteria. This study demonstrated that hence buttressing the information written on two medicated soaps labels they possess antimicrobial activity and fat of $M$. morindoides incorporated at $10 \%$ on basic soap formulation gave an effective antimicrobial power to soap Morinda. Further investigation was to clarify the phytochemical groups of herbal fat responsible for antimicrobial power of soap Morinda.
\end{abstract}

Keywords: Morinda morindoides, herbal fat, medicated soaps, antimicrobial effectiveness, skin pathogens

Cite This Article: TOURE Abdoulaye, MEITE Souleymane, OUATTARA Howele, SORO Yade Rene, DJAMAN Allico Joseph, and COULIBALY Adama, "Comparative Antimicrobial Effectiveness of Two Medicated Soaps with Herbal Soap from Morinda morindoides (Rubiaceae) against Skin Pathogens.” American Journal of Microbiological Research, vol. 5, no. 4 (2017): 74-77. doi: 10.12691/ajmr-5-4-1.

\section{Introduction}

The rising failure of chemotherapeutics and antibiotic resistance exhibited by pathogenic microbial infectious agents has led to the screening of numerous medicinal plants for their biological and pharmacological properties by scientists [1]. Additionally, the less availability and high cost of new generation antibiotics implies looking for the substances from alternative medicines with claimed antimicrobial activity. A number of herbs with significant antimicrobial activity have been reported in different traditional literatures [2]. Traditional medicines are increasingly sought from tradipractitioners and herbalists in Cote d'Ivoire for the treatment of various diseases. Among the plants used, Morinda morindoides is well known in traditional medicine in Cote d'Ivoire and Democratic Republic of Congo for treatment of diarrhea and some parasitic diseases [3,4]. This plant has been subject of several research studies. Also different extracts of leaves of Morinda morindoides are showed some interesting biologicals activities [3,5,6,7,8]. In previous study, extracts of leaves of $M$. morindoides revealed in vitro antifungal and antibacterial properties [9,10]. In order to enhance results of previous research, our team is committed to development of plant derived products to prevent and treat effectively microbial skin infections. In this perspective, the soap Morinda was formulated by incorporating fat extracted from Morinda morindoides as antimicrobial agent in formula of basic soap. In present study two medicated soaps namely Pharmaderm and Micoderme were investigated for their antimicrobial activities compared with soap Morinda against against some clinical strains for skin diseases. The objective of this study consist to test in vitro antimicrobial activities of the two medicated soaps and soap Morinda against clinical microbial strains (Candida albicans, Trichophyton rubrum, 
Trichophyton mentagrophytes, Staphylococcus aureus and Pseudomonas aeruginosa) and to compare effectiveness of their active agents.

\section{Materials and Methods}

\subsection{Collection of Medicated Soaps}

Two brands of the most commonly used medicated soaps namely Pharmaderm and Micoderme were purchased from drug stores in Abidjan District (Cote d'Ivoire). The soap Pharmaderm (ref: 6181100239850) manufactured by Nouvelle Parfumerie Gandour is composed of lauric acid, sodium chloride, coconut oil (Cocos nucifera), shea butter (Butyrospermum parkii), sulfide, salicylic acid, benzoic acid, menthol, camphor and perfume. According to the manufacturer, it is an antiseptic and antimicrobial soap that purifies the epidermis of all impurities. The soap Micoderme (ref: 5468800080) provided by J. K. Cosm. is composed of coconut oil (Cocos nucifera), shea butter (Butyrospermum parkii), soya oil (Glycine max), titanium oxide, sodium silicate, salicylic acid, vitamin E, vitamin F and perfume. According to the manufacturer, it protects the skin against various dermatophytes (dartres, moths), itching and effectively fights against pimples and spots.

\subsection{Herbal Soap from Vegetable Fat of Morinda morindoides}

\subsubsection{Collection of Plant Material}

Leaves of $M$. morindoides (Rubiaceae) were collected from Daloa (central west region of Cote d'Ivoire). The plant was identified and authenticated with voucher specimen no. 17710 in herbarium of National Floristique Center of University Felix Houphouët-Boigny (Cote d'Ivoire).

\subsubsection{Extraction of Vegetable Fat}

Leaves of $M$. morindoides were cleaned of extraneous matter, air-dried at room temperature for 7 days and ground into a fine powder. For each extraction, $100 \mathrm{~g}$ of dry powdered plant material was extracted with $250 \mathrm{ml}$ of hexane (Merck, Darmstadt, Germany) for 24 h using a Soxhlet extractor. Extract was filtered with Whatman filter paper no.1, and evaporated under vacuum in a rotary evaporator (Buchi) at $55^{\circ} \mathrm{C}$. A greenish paste obtained with a yield of $9.24 \pm 0.18 \%$ is fat of $M$. morindoides [9].

\subsection{Preparation of Herbal Soap from Vegetable Fat of Morinda morindoides}

The soap codified Morinda was obtained with the following method. Sodium hydroxide crystals (16.135 g) was dissolved in $59.58 \mathrm{ml}$ of distilled water. The solution of sodium hydroxide obtained will be used after 24 hours. Before its use, $1.5 \mathrm{~g}$ of sodium chloride and $1.2 \mathrm{~g}$ of sodium bicarbonate were added to this solution. This mixture will constitute aqueous phase in production of soap. The fat mixture in preparation of soap consists of 50 $\mathrm{g}$ of coconut oil and $50 \mathrm{~g}$ of palm oil. To obtain basic soap, aqueous mixture was gradually added with stirring to fat mixture. The new mixture obtained was homogenized until a viscous mass (tracing) was formed. To obtain soap Morinda, $10 \mathrm{~g}$ of fat of $M$. morindoides was added to $90 \mathrm{~g}$ of soap mass obtained (basic soap) and then homogenized. Homogeneous mass obtained was poured into the molds. After 24 hours, herbal soap from fat of $M$. morindoides with greenish colored was obtained [11,12].

\subsection{Antimicrobial Assay}

The antimicrobial activity of soaps was assessed by agar broth dilution method coupled with seeding on agar plate using Mueller-Hinton and Sabouraud agar respectively for bacteria and fungi. Each soap was incorporated into growth medium to give serial two fold dilutions with concentrations ranged from 62.50 to $3.90 \mathrm{mg} / \mathrm{ml}$. A medium containing nutrient broth only seeded with the test organisms was served as control of growth. Five clinical isolate strains were tested for antimicrobial activity: one gram-positive bacteria: S. aureus (587/10), one gram-negative bacteria: $P$. aeruginosa $(602 / 10)$ provided by bacteriological laboratory of Pasteur Institute of Cote d'Ivoire; one yeast: C. albicans (3076/PV) and two moulds: T. rubrum (14301/D) and T. mentagrophytes (13801/D) provided by mycology laboratory of medical sciences faculty of university Felix Houphouët-Boigny (Cote d'Ivoire). Biochemical characterization and identification of the test pathogens were carried out using standard identification manual. Fungi cultures were inoculated in growth medium and incubated for 2 to 5 days at $30.0 \pm 0.1^{\circ} \mathrm{C}$ while bacteria cell were inoculated and then incubated at $37^{\circ} \mathrm{C} \pm 2^{\circ} \mathrm{C}$ for 18 hours [9,13,14]. All experiments were performed in triplicate. The activity was estimated by counting the colony of microorganisms. The minimum inhibitory concentration (MIC) was determined after counting the colony of microorganisms of each series. The total score of colony of the control tube was considered as $100 \%$. The MIC is defined as the lowest concentration that produced no visible microbial growth after the incubation time. To determine the minimum bactericidal concentration (MBC) or the minimum fungicidal concentration (MFC) for each set test tubes in the MIC determination, a loopful of broth was collected from those tubes which did not show any growth and inoculated on sterile nutrient agar by streaking. Plates inoculated with bacteria or fungi were then incubated respectively at $37 \pm 2^{\circ} \mathrm{C}$ for 24 hours and at $30 \pm 0.1^{\circ} \mathrm{C}$ for 2 to 5 days. After incubation the concentration at which no visible growth was seen was noted as MBC or MFC [13,14].

\section{Results}

The results of antimicrobial test showed that the pattern of inhibition varied significantly $(p<0.05)$ with the soaps concentrations (Table 1). According to the antimicrobial parameters (Table 2), soap Micoderme exhibited the highest antimicrobial effectiveness with MFC varying from 7.81 to $31.25 \mathrm{mg} / \mathrm{ml}$ and $\mathrm{MBC}$ of $15.62 \mathrm{mg} / \mathrm{ml}$. The soaps Morinda and Pharmaderm showed similar antibacterial activities with MBC of $31.25 \mathrm{mg} / \mathrm{ml}$. But, against fungi, soap Morinda with MFC of $31.25 \mathrm{mg} / \mathrm{ml}$ was more effectiveness than soap Pharmaderm with MFC of $62.50 \mathrm{mg} / \mathrm{ml}$. T. mentagrophytes with MFC of 7.81 
$\mathrm{mg} / \mathrm{ml}$ was the most sensitive whereas C. albicans $(62.50$ $\mathrm{mg} / \mathrm{ml})$ and $T$. rubrum $(31.25 \mathrm{mg} / \mathrm{ml})$ were the least strains with respective MFC of $62.50 \mathrm{mg} / \mathrm{ml}$ and 31.25 $\mathrm{mg} / \mathrm{ml}$ in presence of soap Micoderme. Whereas $S$. aureus and $P$. aeruginosa with CMB of $15.62 \mathrm{mg} / \mathrm{ml}$ presented intermediate sensitivity against this soap.

Table 1. Inhibitory effects of soaps on in vitro growth of microorganisms tested

\begin{tabular}{|c|c|c|c|c|c|c|c|}
\hline \multicolumn{8}{|c|}{ Soap concentrations (mg/ml) } \\
\hline Microorganisms & Soaps & $\mathbf{0}$ & 3.90 & 7.81 & 15.62 & 31.25 & 62.50 \\
\hline \multirow{3}{*}{ Candida albicans } & $\mathrm{S}_{\mathrm{PHA}}$ & $100 \pm 0.2^{\mathrm{a}, \mathrm{b}}$ & $57 \pm 0.4^{\mathbf{b}, \mathbf{e}}$ & $31 \pm 0.7^{\mathrm{d}, \mathrm{e}}$ & $19 \pm 0.8^{c}$ & $6 \pm 0.3^{\mathrm{a}, \mathrm{c}}$ & $0 \pm 0.0$ \\
\hline & $\mathrm{S}_{\mathrm{MIC}}$ & $100 \pm 0.6^{c}$ & $33 \pm 0.8^{\mathbf{b , c}}$ & $8 \pm 0.1^{\mathrm{a}, \mathrm{b}}$ & $0 \pm 0.0$ & $0 \pm 0.0$ & $0 \pm 0.0$ \\
\hline & $\mathrm{S}_{\mathrm{MOR}}$ & $100 \pm 0.2^{\mathrm{b}}$ & $75 \pm 0.4^{\mathrm{c}, \mathrm{e}}$ & $58 \pm 0.7^{\mathrm{a}, \mathrm{c}}$ & $24 \pm 0.8^{\mathrm{d}}$ & $0 \pm 0.0$ & $0 \pm 0.0$ \\
\hline \multirow{3}{*}{ Trichophyton rubrum } & $\mathrm{S}_{\mathrm{PHA}}$ & $100 \pm 0.1^{\mathbf{b}, \mathbf{c}}$ & $40 \pm 0.4^{\mathrm{a}, \mathrm{d}}$ & $12 \pm 0.8^{\mathbf{c}, \mathbf{e}}$ & $4 \pm 0.3^{\mathbf{a}, \mathbf{b}}$ & $0 \pm 0.0$ & $0 \pm 0.0$ \\
\hline & $\mathrm{S}_{\mathrm{MIC}}$ & $100 \pm 0.6^{\mathbf{b , d}}$ & $25 \pm 0.7^{\mathrm{c}, \mathrm{e}}$ & $6 \pm 0.2^{\mathrm{a}, \mathrm{c}}$ & $0 \pm 0.0$ & $0 \pm 0.0$ & $0 \pm 0.0$ \\
\hline & $\mathrm{S}_{\mathrm{MOR}}$ & $100 \pm 0.2^{\mathrm{c}, \mathrm{e}}$ & $28 \pm 0.4^{\mathrm{a}, \mathrm{e}}$ & $12 \pm 0.7^{\mathrm{c}, \mathrm{d}}$ & $3 \pm 0.8^{\mathbf{b}, \mathbf{e}}$ & $0 \pm 0.0$ & $0 \pm 0.0$ \\
\hline \multirow{3}{*}{ Trichophyton mentagrophytes } & $\mathrm{S}_{\mathrm{PHA}}$ & $100 \pm 0.3^{\mathrm{a}}$ & $20 \pm 0.2^{\mathrm{a}, \mathrm{e}}$ & $9 \pm 0.6^{\mathbf{b}, \mathbf{d}}$ & $3 \pm 0.7^{\mathbf{c}, \mathbf{e}}$ & $0 \pm 0.0$ & $0 \pm 0.0$ \\
\hline & $\mathrm{S}_{\mathrm{MIC}}$ & $100 \pm 0.5^{c}$ & $16 \pm 0.8^{\mathbf{b , d}}$ & $0 \pm 0.0$ & $0 \pm 0.0$ & $0 \pm 0.0$ & $0 \pm 0.0$ \\
\hline & $\mathrm{S}_{\mathrm{MOR}}$ & $100 \pm 0.2^{\mathrm{a}, \mathrm{c}}$ & $20 \pm 0.4^{\mathrm{c}, \mathrm{e}}$ & $9 \pm 0.7^{\mathbf{a}, \mathbf{d}}$ & $2 \pm 0.8^{\mathrm{b}, \mathrm{c}}$ & $0 \pm 0.0$ & $0 \pm 0.0$ \\
\hline \multirow{3}{*}{ Staphylococcus aureus } & $\mathrm{S}_{\text {PHA }}$ & $100 \pm 0.4^{\mathrm{a}, \mathrm{b}}$ & $60 \pm 0.6^{\mathbf{b , c}}$ & $35 \pm 0.7^{c, d}$ & $8 \pm 0.8^{\mathbf{b , e}}$ & $0 \pm 0.0$ & $0 \pm 0.0$ \\
\hline & $\mathrm{S}_{\mathrm{MIC}}$ & $100 \pm 0.2^{\mathbf{b}, \mathbf{d}}$ & $40 \pm 0.3^{\mathrm{a}, \mathrm{e}}$ & $5 \pm 0.6^{\mathbf{a}}$ & $0 \pm 0.0$ & $0 \pm 0.0$ & $0 \pm 0.0$ \\
\hline & $\mathrm{S}_{\mathrm{MOR}}$ & $100 \pm 0.2^{\mathbf{c}, \mathbf{b}}$ & $31 \pm 0.4^{\mathrm{c}, \mathrm{d}}$ & $15 \pm 0.7^{\mathrm{d}, \mathrm{e}}$ & $15 \pm 0.7^{\mathrm{d}, \mathrm{e}}$ & $0 \pm 0.0$ & $0 \pm 0.0$ \\
\hline \multirow{3}{*}{ Pseudomonas aeruginosa } & $\mathrm{S}_{\text {PHA }}$ & $100 \pm 0.3^{\mathbf{c , d}}$ & $35 \pm 0.4^{\mathrm{a}, \mathrm{d}}$ & $16 \pm 0.6^{\mathbf{b}, \mathbf{e}}$ & $5 \pm 0.3^{\mathbf{a}, \mathbf{b}}$ & $0 \pm 0.0$ & $0 \pm 0.0$ \\
\hline & $\mathrm{S}_{\mathrm{MIC}}$ & $100 \pm 0.1^{\mathrm{a}, \mathrm{e}}$ & $13 \pm 0.2^{c, e}$ & $0 \pm 0.0$ & $0 \pm 0.0$ & $0 \pm 0.0$ & $0 \pm 0.0$ \\
\hline & $\mathrm{S}_{\mathrm{MOR}}$ & $100 \pm 0.2^{\mathrm{a}, \mathrm{b}}$ & $23 \pm 0.4^{\mathbf{b}, \mathbf{e}}$ & $9 \pm 0.7^{\mathrm{d}, \mathrm{e}}$ & $2 \pm 0.8^{c}$ & $0 \pm 0.0$ & $0 \pm 0.0$ \\
\hline
\end{tabular}

$\mathrm{S}_{\mathrm{PHA}}$ : soap Pharmaderm; $\mathrm{S}_{\mathrm{MIC}}$ : soap Micoderme; $\mathrm{S}_{\mathrm{MOR}}$ : soap Morinda; Mean $\pm \mathrm{SEM}(\mathrm{n}=3)$; ${ }_{a, b, c, c, d, e}$ Mean values with same superscript within a row do not differ significantly $(\mathrm{p}<0.05)$.

Table 2. Antifmicrobial parameters ( $\mathrm{mg} / \mathrm{ml})$ of soaps against microorganisms tested.

\begin{tabular}{|c|c|c|c|c|}
\hline Microorganisms & Savons & MIC & MFC & MBC \\
\hline \multirow{3}{*}{ Candida albicans } & $\mathrm{S}_{\mathrm{PHA}}$ & 62.50 & 62.50 & - \\
\hline & $\mathrm{S}_{\mathrm{MIC}}$ & 15.62 & 31.25 & - \\
\hline & $\mathrm{S}_{\mathrm{MOR}}$ & 31.25 & 31.25 & - \\
\hline \multirow{3}{*}{ Trichophyton rubrum } & $\mathrm{S}_{\mathrm{PHA}}$ & 31.25 & 31.25 & - \\
\hline & $\mathrm{S}_{\mathrm{MIC}}$ & 15.62 & 31.25 & - \\
\hline & $\mathrm{S}_{\mathrm{MOR}}$ & 31.25 & 31.25 & - \\
\hline \multirow{3}{*}{ Trichophyton mentagrophytes } & $\mathrm{S}_{\mathrm{PHA}}$ & 31.25 & 31.25 & - \\
\hline & $\mathrm{S}_{\mathrm{MIC}}$ & 7.81 & 7.81 & - \\
\hline & $\mathrm{S}_{\mathrm{MOR}}$ & 31.25 & 31.25 & - \\
\hline \multirow{3}{*}{ Staphylococcus aureus } & $\mathrm{S}_{\mathrm{PHA}}$ & 31.25 & - & 31.25 \\
\hline & $\mathrm{S}_{\mathrm{MIC}}$ & 15.62 & - & 15.62 \\
\hline & $\mathrm{S}_{\mathrm{MOR}}$ & 31.25 & - & 31.25 \\
\hline \multirow{3}{*}{ Pseudomonas aeruginosa } & $\mathrm{S}_{\mathrm{PHA}}$ & 31.25 & - & 31.25 \\
\hline & $\mathrm{S}_{\mathrm{MIC}}$ & 7.81 & - & 15.62 \\
\hline & $\mathrm{S}_{\mathrm{MOR}}$ & 31.25 & - & 31.25 \\
\hline
\end{tabular}

$\mathrm{S}_{\text {PHA: }}$ : soap Pharmaderm, $\mathrm{S}_{\text {MIC }}$ : soap Micoderme, $\mathrm{S}_{\text {MOR }}$ soap Morinda. 


\section{Discussion}

Results of this study revealed that all of the assayed soaps have antimicrobial activity, through to varying degrees as indicated by inhibition of growth pattern of the strains. Soap Micoderme was found to be most effective against all the skin pathogens tested. T. mentagrophytes was the most sensitive whereas $C$. albicans and T. rubrum were the least strains in presence of soap Micoderm. Whereas $S$. aureus and $P$. aeruginosa presented intermediate sensitivity against this soap. It was clearly seen from this study that hence buttressing the information written on the two medicated soaps labels they possess antimicrobial activity and the fat of $M$. morindoides incorporated at $10 \%$ on basic soap formulation gave an effective antimicrobial power to soap Morinda. Also, soap Micoderme which ingredients were not recognized to possess antimicrobial properties was effective than soap Pharmaderm with sulfide as active compound. These variations of effectiveness of soaps tested is due to differences in the active antimicrobial ingredients and type of formulations used [15]. This finding corroborated with research work of Aminuddin et al. Soap containing aqueous extract of leaf of Senna alata (L.) Roxb tested at concentration of $100 \mu \mathrm{g} / \mathrm{ml}$ by these authors was no active against $P$. aeruginosa ATCC-27853 and S. aureus ATCC-29213 [16]. They concluded that the lack of activity against bacteria tested was due to low concentration of extract of Senna alata. Antimicrobial activities of commercial medicated soaps (Crusader and Antigal) were evaluated by Obi against S. aureus [17]. This study revealed that the soaps Crusader and Antigal whose antimicrobial agents are synthetic compounds (trichlocarban and tricloson) had respective MICs of 62.5 $\mathrm{mg} / \mathrm{ml}$ and $500 \mathrm{mg} / \mathrm{ml}$ against $S$. aureus. According to these results soap Morinda containing naturel active compound have best antimicrobial potential to be used as medicated soap. The present study demonstrated the broad microbicidal effectiveness of fat of $M$. morindoides on soap Morinda against cutaneous pathogens, including gram-positive and gram-negative bacteria and fungi. This finding supported a potential of soap Morinda with natural antimicrobial agent as a promising medicated product to prevent and cure skin infections. Further investigation was to clarify the phytochemical groups of herbal fat responsible for antimicrobial power of soap prepared from $M$. morindoides.

\section{Acknowledgments}

The authors thank to the Director of Pasteur Institute of Cote d'Ivoire and the Director of Medical Sciences Faculty of University Felix Houphouet-Boigny (Cote d'Ivoire) for providing microbial test material.

\section{Conflict of Interest}

No conflict of interest associated with this work.

\section{References}

[1] Abdelaaty A, Shahat E A, Mahmoud A A, Al-Mishari M, Alsaid S, Antimicrobial activities of some Saudi Arabian herbal plants, African Journal Traditionnal Complementary Alternative Medecine, 14: 161-165, 2017.

[2] Saravanan R, Dhachinamoorthi D, Senthilkumar K, Thamizhvanan K, Antimicrobial activity of various extracts from various parts of Calophyllum inophyllum L, Journal Applied Pharmaceutical Sciences 1: 102-106, 2011.

[3] Zirihi GN, Mambu L, Guede-Guede F, Bodo B, Grellier P, In vitro antiplasmodial activity and cytotoxicity of 33 West African plants used for the treatment of malaria, Journal Ethnopharmacology, 98: 281-285, 2005.

[4] Cimanga K, Kambu K, Tona L, Hermans N, Apers S, Totté J, Pieters L and Vlietinck AJ, Cytotoxicity and in vitro susceptibility of Entamoeba histolytica to Morinda morindoides leaf extracts and its isolated constituents, Journal Ethnopharmacology, 107: 83-90, 2006.

[5] Bagre I, Bahi C, Gnahoue, Djaman AJ and Guede-Guina F, Phytochemical composition and evaluation of in vitro antifungal activity of leaves of Morinda morindoides (Baker) Milne-redh (Rubiaceae) against Aspergillus fumigatus and Candida albicans, Journal Sciences Pharmacology Biology, 8: 15-23, 2007.

[6] Moroh JLA, Bahi C, Dje K, Loukou YG and Guede-Guina F, Study of the antibacterial activity of Morinda morindoides (Baker) Milne- Readhead (Rubiaceae) acetatique extract (ACE) on in vitro growth of Escherichia coli strains, Bulletin Société Royale Sciences Liege, 77: 44-61, 2008

[7] Meite S, N'guessan JD, Bahi C, Yapi HF, Djaman AJ and GuedeGuina F, Antidiarrheoal activity of the ethyl acetate extract of Morinda morindoides in rats, Tropical Journal Pharmaceutical Research, 8: 201-207, 2009.

[8] Cimanga K, De Bruyne T, Lasure A, Li Q, Pieters L, Claeys M, Vanden Berghe D, Kambu K, Tona L and Vlietinck AJ, Flavonoid o-glycosides from the leaves of Morinda morindoides, Phytochemistry, 38: 1301-1303, 1995.

[9] Toure A, Bahi C, Ouattara K, Djaman AJ, Coulibaly A, Phytochemical screening and in vitro antifungal activities of extracts of leaves of Morinda morindoides (Morinda, Rubiaceae), Journal Medicinal Plant Research, 5(31): 6780-6786, December 2011.

[10] Ouattara K, Doumbia I, Touré A, Djaman AJ, Coulibaly A, Activité antibactérienne des extraits des feuilles de Morinda morindoides (Morinda, Rubiaceae) sur Staphylococcus aureus et Pseudomonas aeruginosa, Phytotherapie, 11:172-177, 2013.

[11] Kareru PG, Keriko JM, Kenji GM, Thiong’o GT, Gachanja AN, Mukiira HN, Antimicrobial activities of skincare preparations from plants extracts, African Journal Traditionnal Complementary Alternative Medicine, 7(3): 214-218, 2010.

[12] Oladele AT, Dairo BA, Elujoba AA, Oyelami AO, Management of superficial fungal infections with Senna alata ("alata") soap: preliminary report, African Journal Pharmacy Pharmacology, 4: 98-103, 2010.

[13] Saba R, Adeel A, Shahida H, Antibacterial activity of soaps against daily encountered bacterial, African Journal Biotechnology, 8: 1431-1436, 2009.

[14] Selvamohan V, Sandhya T, Studies on the bactericidal activity of different soaps against bacterial strains, Journal Microbiology Biotechnology Research. 2(5): 646- 650, 2012.

[15] Nwambete KD, Lyombe F, Antimicrobial activity of medicated soaps commonly used by Dares Salam residents in Tanzania, Indian Journal Pharmaceutical sciences, 73(1): 92-98, JanuaryFebruary 2011.

[16] Aminuddin MF, Basri AM, Taha H, Abidin AM, Ahmad N, Antimicrobial activities of soaps containing Senna alata leaf extract, Biological Sciences Brunei. 15: 44-47, 2016.

[17] Obi. CN, Antibacterial activities of some medicated soaps on selected human pathogens, American Journal Microbiology Research, 2(6): 178-181, 2014. 